\title{
Assessment of Floristic Diversity and its Structural Composition in South Gujarat
}

\author{
N. Chaudhari and B. Pathak \\ School of Environment and Sustainable Development \\ Central University of Gujarat, Gandhinagar-382 030, India \\ ${ }^{*} E$-mail: bhawana.pathak@cug.ac.in
}

\begin{abstract}
The study deals with the status of floristic diversity and its structural composition in South Gujarat, Tehsil-Mandvi. District-Surat, Stratified random sampling method was used for vegetation assessment. Total 77 plant species were recorded from the study site out of that total of 47 tree species, 20 shrub species, 3herbs, 2 climbers, 2 grass and 1 weed species belonging to 18 families. Vegetation analysis revealed that plant communities were dominated by the family Lamiaceae, Rhamnaceae and Asteraceae which indicatea huge difference in site conditions. The higher level of diversity and the high basal area of woody plant species representthe good condition of the forest. However, the effect of anthropogenic activities and stresses areobserved so that proper management for maintaining or enhancing the present species diversity is needful. Butea monosperma, Tectona grandis, Terminalia arjunaandTerminalia crenulata were the most dominant species documented from the study site which containsthe highest biomass and carbon. Nearly all the specific plant species show the contagious distribution pattern. The value of the Shannon index shows the extremely high diversity of all the plant habits except shrub species.
\end{abstract}

Keywords: Floristic diversity, Structural composition, Species diversity, Biomass, Carbon sequestration

Biodiversity is critical for the survival of humans, economic wellbeing and the functioning or stability of the ecosystem (Singh, 2002). The diversity of trees provides resources and habitat for nearly all other life forms of forest. The tree species diversity varies significantly with the variation in biogeography and habitat disturbance (Ali et al 2018). Diversity at all structural levels, changing from the genetic diversity of the ecosystem in a landscape, contributes ultimately to global biodiversity. In particular, species diversity has functional importance, because the number and types of species existing at any place determine the organismic characteristics which influence the ecosystem process (Chapin lii et al 2000). Floristic diversity within a specific area is referred to as the variety of plant species scattered in a particular area, which is based on climate conditions, the appearance of vegetation and biotic influences (Gaston and Spicer 2013). A complete report of plant species existing in any geographic region is very essential for the identification of characteristic features of different types of land use classes. Floristic diversity is a reflection of environmental conditions, physiognomy and biotic influences (Ali et al 2018) Besides, floristic diversity is a vital foundation for most of our terrestrial ecosystems. Human beings and faunas are completely relying on plant species, by the means of energy source over their capability for converting the sun's energy by the process of photosynthesis. However, due to anthropogenic activities, urbanization, climate change and over-exploitation of natural resources, people are becoming gradually dissociated from nature.

To assess the plant biodiversity of an area vegetation/phytosociological analysis is the crucial activity as a state of vegetation. This data not only describes the health of the commons but also determines the range of resources available that its provisions and the composition of users. The structural analysis encompasses the study of vegetation and its internal "social" relationships and also provides information on classifications of plant communities' composition and successional relations.

Forests regulate local and regional rainfall and also play a major role in slow down global warming by storing or sequestering carbon (Eliasch 2008). Consequently, they impact global atmospheric carbon levels and, in turn, are influenced by atmospheric carbon levels and related climate change (Kellogg 2019). Mandvi forest can play in the mitigation of climate change via carbon sequestration and help in the proper management of the forest with positive implications for forest conservation. Understanding the economic value of carbon sequestered in forests is important in addressing the risk of global climate change that has presented a profound challenge to the international community. The forest needs to be saved from the pressure of human activities such as illegal cutting, cultivation, overgrazing, encroachment, poaching and increased 
human-wildlife conflicts. Currently, Forest was protected by local, government, and forest departments for the resources and economic benefits of the forest The forest area which is being protected by the community too but the proper management of this forest area is crucial for the survival of people who directly depend on the forest for their livelihood. Therefore, to protect the forest ecosystem, research on biodiversity with a participatory approach for the conservation and management of forest resources is essential. The present study will highlight the current status of vegetation and its structure in the forest.

\section{MATERIAL AND METHODS}

Site selection and data collection: The study site was selected using ground inventories and present study has been carried out in selected villages of Mandvi (Tehsil), Surat (District), South Gujarat region (Fig. 1). Mandvi is situated at an altitude of 50 meters and $113 \mathrm{~km}$ (Arial distance) from the sea coast. Villages named Regama, Raghipura, Khodamba, Kalibel, Titoi and Parva of Mandvi were selected for data collection. These villages are in a tribal area with average annual rain is $1701.8 \mathrm{~mm}$. The area has a dry deciduous type of forest. Commercial land use is broadly mixed type. However, in another part of the town slum area, agricultural land, wasteland, and hilly area are also present.

Field survey and vegetation sampling: Floristic diversity and assessment survey has been carried out in the forest region of Mandvi. A total of 50 plots were taken for vegetation data collection by using stratified random sampling. The vegetation study was carried out on the selected sites during December 2018 to January 2019. The collected unidentified plants are dried and pressed properly. The moisture on the plants was absorbed by a clean paper. After that, the plant herbarium sheets were made for further identification. The inventory of plants was identified using the digital flora of Gujarat website (www.gujaratflora.com) and GEER Foundation, Gandhinagar.

Measurement of diameter at breast height (DBH): All the vegetation such as trees, shrubs, herbs and grasses were considered for the structural composition analysis. The sample plot size was set to 314 sq. meters ( $10 \times 10$ meters) quadrate for trees having a girth above $10 \mathrm{~cm}$ at breast height $(\mathrm{DBH})$. A subplot of 28 sq. meters quadrate $(3 \times 3$ meters $)$ was nestled within the sample plot to get the information of shrubs, saplings/regeneration (<10 cm DBH) (Stohlgren et al 1995).

Structural composition: Various measures of the physiognomy of the area such as basal area, density, abundance, frequency, dominance, diversity indices, and importance value index (IVI), density per hectare and abundance to frequency ratio were examined. In specific, IVI is considered as one of the most significant ecological attributes for understanding the community (Ratter et al 2003). IVI is based on the total sum of relative frequency, relative dominance and relative density. IVI of the particular species in the ecosystem exhibits their dominance in trapping the available resources. The higher value of IVI shows the higher dominance of particular species that reflecting the maximum utilization of available resources. Species diversity was determined by Shannon index $(H)$, Simpson's index of diversity (1-D) (Shannon and Weaver 1949), (Kerkhoff 2010). Regenertion status of the forest was examined according to Dhaulkhandi et al (2008) and Tiwari et al (2018) by comparing seedlings and saplings with the matured woody tree species that means the regeneration status is good), if seedlings > saplings > mature (fair regeneration), if seedlings $>$ or $\leq$ saplings $\leq$ mature species (poor regeneration), if the species survives only in sapling stage (saplings may be $\leq$ or $\geq$ mature); and if a species is present only in an mature woody plants form it is reflected as not regenerating status.

Shannon and Simpson index: The Shannon index $\left(\mathrm{H}^{\prime}\right)$ was calculated by the following equation.

$$
H^{\prime}=-\sum_{i=1}^{s} p_{i} \ln p_{i}
$$

The Simpson index (D) was calculated by the following equation.

$$
D=\frac{1}{\sum_{i=1}^{s} p_{i}^{2}}
$$

Where $p_{i}=n i / N$; $n$ is the number of individual trees present for species $\mathrm{i}, \mathrm{N}$ is the total number of individuals, and $S$ is the total number of species (Shirima et al 2015).

Biomass: Sample plots with diameters of 10-meters were taken from the forest to estimate the above-ground tree biomass by using non-destructive methods. $\mathrm{DBH}$ and height (in meter) of all the tree species within the plot were noted and extrapolated for the entire study area. The equation developed by(Brown, 1997)was used for calculating the biomass for the tree species.

Tree Biomass $(\mathrm{kg})=\operatorname{Exp}^{[-2.134+(2.530 \times \operatorname{lnD})]}(3)$

Where following assumptions were used for the calculation of biomass of dominant species.

Volume $\left(\right.$ meter $\left.^{3}\right)=(3.14 \times \mathrm{DBH} \times \mathrm{DBH} \times$ height $) / 4(4)$

Conversion of green weight to volume of wood is 1 meter ${ }^{3}$ and weight $2118 \mathrm{~kg}$. The dry weight of wood was taken $46 \%$ of the green weight.

Estimation of forest carbon: The carbon sequestration value was calculated. The carbon content equals to $45-47 \%$ of dry biomass (Aalde et al 2006) (IPCC 2006, Tewari and Karki 2007).

$$
\mathrm{CO}_{2} \text { Stock }=\text { Biomass }(\text { ton } / \text { ha }) \times 45 / 100(5)
$$




\section{RESULTS AND DISCUSSION}

The local inhabitants depend on the forest for grazing and forest product (firewood, fodder and other products are Timaru leave for making bidis and fruits of Mahuda for making alcohol, Kadaya tree mainly for Gum). The fuelwood is collected by communities together twice a year, first before the rainy season and second after the harvesting season. Forest has no entry restriction and grazing restriction to the forest area but the community also conserved the forest and protects the forest resources for their better livelihood.

Plant species: The 77 plant species were recorded from the study site, tree species, 20 shrub species, 3 herbs, 2 climbers, 2 grass and 1 weed species belonging to 18 families were recorded from the study area (Table 1). The structural composition of the plant species includes a total $61 \%$ of tree species, $26 \%$ shrub, $4 \%$ herbs, $5 \%$ climbers, $4 \%$ of grass were distributed at the study site (Fig. 2). The area was covered by the highest percent of mature woody trees followed by shrub, herbs. Climbers and grasses. The percentage of grasses, herbs, and climbers is less may be due to overgrazing and the autumn season. So there is an urgent need to focus on the newly planted species.

\section{Structural Characteristics}

Tree: The 49 species of mature trees were recorded and the importance value index (IVI) showing that Butea monosperma $(17.85 \%)$ was dominant and this species exploited maximum resources across all the sites, (Table 2) followed by Tectona grandis, Terminalia arjuna (total), Terminalia crenulata, Miliusa tomentosa, Azadirachta indica. All the three attributes relative density, relative frequency, and relative dominance are high for Butea monosperma, Tectona grandis, Terminalia arjuna, and Terminalia crenulata showing that these species are well distributed in the area. Higher value of relative frequency as compared to relative dominance and relative density of Terminalia crenulata \& Milius tomentosa shows that small trees of this species frequently occurred at the study site. Less value of all three attributes of including IVI of rest of the species indicate that only a few numbers of rest of the species were present at the study area. The distribution pattern of species was determined by the ratio of abundance to frequency if the ratio is below 0.025 then it indicates regular distribution, between 0.025-0.050 indicates the random distribution, and when exceeds 0.050 indicates contagious distribution (Curtis 1956).

Regeneration status: About 25 species of saplings were present at the study site (Table 3). Importance value index (IVI) showing that Butea monosperma ( $31 \%$ of total) is dominant like tree habit and Tectona grandis, Canavalia ensiformis, Dyospyros melanoxylon, Terminalia arjuna,
Acacia catechu are co-dominant species. All the three attributes relative density, relative frequency, and relative dominance are high for Butea monosperma, Tectona grandis, Canavalia ensiformis and Dyospyros melanoxylon showing that these species are well distributed in the area. Higher value of relative frequency as compared to relative dominance and relative density of Terminalia arjuna \& Acacia catechu shows that saplings, these species frequently occurred at the study site. Less value of all three attributes of including IVI of rest of the species shows that only a few numbers of rest of the species are present at the study area. In the present study area the regeneration status is also poor regenerating status because the seedlings $\geq$ sapling $\leq$ mature woody trees.

Shrubs: Nine species of the shrub were recorded from the study area (Table 4). Importance value index (IVI) showing

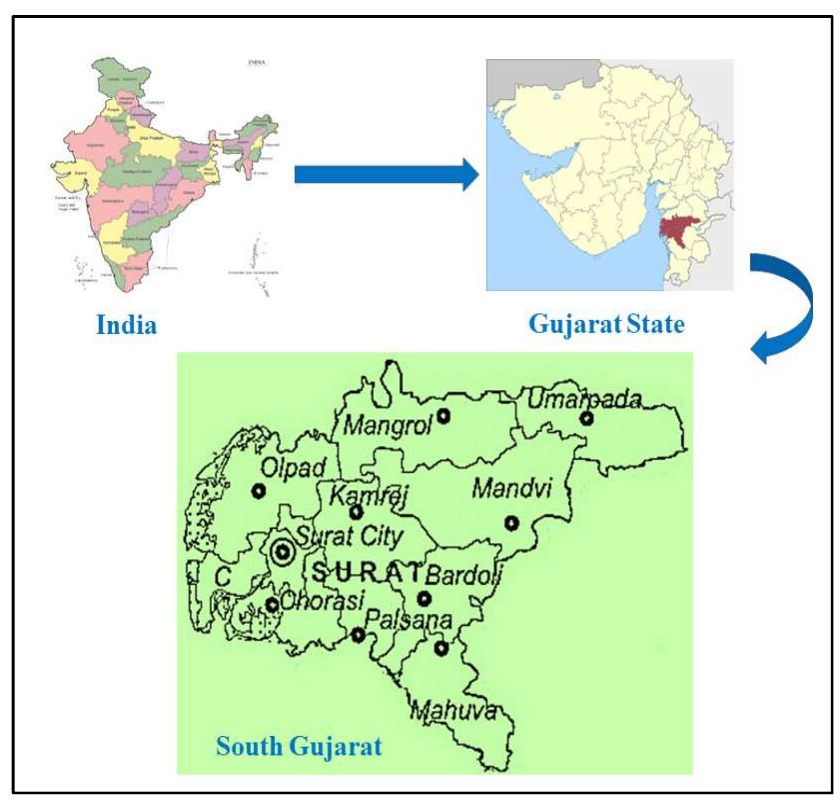

Fig. 1. Map of the study site

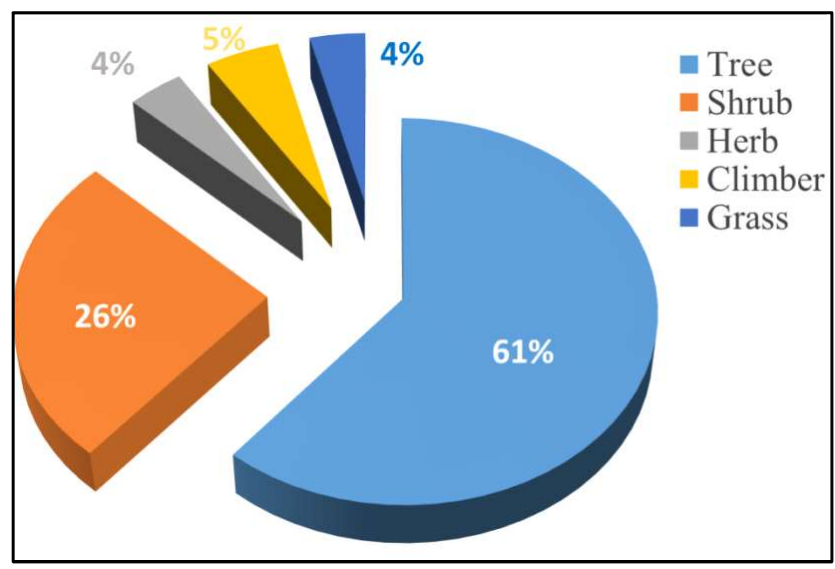

Fig. 2. Percent wise distribution of plant species 
Table 1. Plant species recorded from the study site

\begin{tabular}{|c|c|c|c|}
\hline English name & Botanical name & Family & Habit \\
\hline Dwarf Heliotrope & Heliotropium supinum & Boraginaceae & Herb \\
\hline Malkangani & Celastrus paniculatus & Celastraceae & Climber \\
\hline Famado & Canavalia ensiformis & Fabaceae & Climber \\
\hline Bhoybala & Sida cordata & Malvaceae & Herb \\
\hline Mollugo & Mollugo verticillata & Mollunginaceae & Weed \\
\hline Bamboo & Bambusa vulgaris & Poaceae & Long grass \\
\hline Asi, Asvel & Ventilago denticulata & Rhamnaceae & Climber \\
\hline Devahehaldo & Curcuma arometica & Zingiberaceae & Herb \\
\hline Gado & Tinospora cordifolia & Menispermacea & Climber \\
\hline Congress grass & Parthenium hysterophorus & Asteraceae & Grass \\
\hline Ghans & Cynodon dactylon & Poaceae & Grass \\
\hline Karavu & Erenthemum pulchellum & Acanthaceae & Shrub \\
\hline Ankdo & Calotropis gigantean & Apocynaceae & Shrub \\
\hline Karamda & Carissa Carandas & Apocynaceae & Shrub \\
\hline Dudhilu & Wrightia tinctoria $R . B r$ & Apocynaceae & Shrub \\
\hline Kudi & Holorrhena antidysenterica & Apocynaceae & Shrub \\
\hline Kachku & Ceasalpinia bonduc & Caesalpiniaceae & Shrub \\
\hline Nashedi & Ipomea fistula & Convolvulaceae & Shrub \\
\hline Kamboi & Phyllanthus reticulatus & Euphorbiaceae & Shrub \\
\hline Jungali arenda & Ricinus communis & Euphorbiaceae & Shrub \\
\hline Chanothi & Abrus pricatorious Linn. & Fabaceae & Shrub \\
\hline Kuvach & Mucuna pruriens & Fabaceae & Shrub \\
\hline Babool & Vachellia nilotica & Fabaceae & Shrub \\
\hline Nirgundi & Vitex nirgunda & Lamiaceae & Shrub \\
\hline Pembadiyu & Cassia tora & Leguminosae & Shrub \\
\hline Bor & Zizyphus mauritiana & Rhamnaceae & Shrub \\
\hline Chanibor & Zizyphus nummulatria & Rhamnaceae & Shrub \\
\hline Ghatbor & Ziziphus xyiopyra & Rhamnaceae & Shrub \\
\hline Motabor & Ziziphus jujuba & Rhamnaceae & Shrub \\
\hline Chamatoda & Ziziphus oenoplia & Rhamnaceae & Shrub \\
\hline Gongadu & Lantana camara & Verbenaceae & Shrub \\
\hline Kaju & Anacardium occidentale, $L$ & Anacardiaceae & Tree \\
\hline Mahudo & Madhuca longifolia & Sapotaceae & Tree \\
\hline Madhlo & Lannea coromandelica & Anacardiaceae & Tree \\
\hline Sitafal & Annona squamosal & Annonaceae & Tree \\
\hline Umbha & Miliusa tomentosa & Annonaceae & Tree \\
\hline Med singu & Dolicandrone falcate & Bignoniaceae & Tree \\
\hline Gundo & Cordia dichotoma & Boraginaceae & Tree \\
\hline Kakdo & Garuga pinnata Roxb & Burseraceae & Tree \\
\hline
\end{tabular}


Table 1. Plant species recorded from the study site

\begin{tabular}{|c|c|c|c|}
\hline English name & Botanical name & Family & Habit \\
\hline Kojalo & Bauhinia purpurea & Caesalpiniaceae & Tree \\
\hline Ashitro & Bauhinia racemosa Lam & Ceasalpiniaceae & Tree \\
\hline Dhamdo & Anogeissus latifolia & Combretaceae & Tree \\
\hline Baheda & Terminalia bellirica & Combretaceae & Tree \\
\hline Arjun Sadad & Terminalia arjuna & Combretaceae & Tree \\
\hline Safed Sadad & Terminalia crenulata & Combretaceae & Tree \\
\hline Ankol/Akinu & Alangium salviifolium & Coranaceae & Tree \\
\hline Timaru & Diospyros melanoxylon & Ebenaceae & Tree \\
\hline Khakhro & Butea monosperma & Fabaceae & Tree \\
\hline Garmado & Cassia fistula & Fabaceae & Tree \\
\hline Sheesham & Dalbergia sissoo & Fabaceae & Tree \\
\hline Karanj & Pongamia pinnata & Fabaceae & Tree \\
\hline Gor baval & Prosopis juliflora & Fabaceae & Tree \\
\hline Amli & Tamarindus indica & Fabaceae & Tree \\
\hline Saag & Tectona grandis & Lamiaceae & Tree \\
\hline Kher & Acacia catechu & Leguminosae & Tree \\
\hline Samar & Bombax ceabae & Malvaceae & Tree \\
\hline Neem & Azadirachta indica & Meliaceae & Tree \\
\hline Kalohero & Albizia labbeck & Mimosaceae & Tree \\
\hline Vad & Ficus benghalensis & Moraceae & Tree \\
\hline Karveto & Ficus hispida & Moraceae & Tree \\
\hline Umar & Ficus racemosa $L$. & Moraceae & Tree \\
\hline Peepal & Ficus religiosa & Moraceae & Tree \\
\hline Atayu & Ficus amplissima & Moraceae & Tree \\
\hline Peepali & Ficus virens & Moraceae & Tree \\
\hline Nilgiri & Eucalyptus hybrid & Myrtaceae & Tree \\
\hline Hakano & Bridelia retusa & Phyllanthaceae & Tree \\
\hline Amla & Phyllanthus emblica & Phyllanthaceae & Tree \\
\hline Thumro & Securinega leucopyrus & Phyllanthaceae & Tree \\
\hline Bor & Zizyphus mauritiana & Rhamnaceae & Tree \\
\hline Kanabo/ Kalam & Mitragyna parvifolia & Rubiaceae & Tree \\
\hline Anudo & Morinda pubescens & Rubiaceae & Tree \\
\hline Kadamb & Neolamarckia cadamba & Rubiaceae & Tree \\
\hline Bili & Aegle marmelos & Rutaceae & Tree \\
\hline Rayan & Manilkara Hexandra & Sapotaceae & Tree \\
\hline Arduso & Ailanthus excels & Simaroubaceae & Tree \\
\hline Kadayu & Sterculia urens & Sterculiaceae & Tree \\
\hline Kanajo /Kukranj & Holoptelea integrifolia & Ulmaceae & Tree \\
\hline
\end{tabular}


Table 2. Vegetation parameters of tree species

\begin{tabular}{|c|c|c|c|c|c|}
\hline Name of species & Relative density & Relative frequency & $\begin{array}{c}\text { Relative } \\
\text { dominance }\end{array}$ & $\begin{array}{l}\text { Important value } \\
\text { Index }\end{array}$ & $\begin{array}{c}\text { Abundance/Frequ } \\
\text { ency ratio }\end{array}$ \\
\hline Butea monosperma & 21.31 & 14.18 & 18.05 & 53.55 & 0.10 \\
\hline Tectona grandis & 18.79 & 10.76 & 13.55 & 43.10 & 0.15 \\
\hline Terminalia arjuna & 9.71 & 7.82 & 8.69 & 26.22 & 0.15 \\
\hline Terminalia crenulata & 5.80 & 5.87 & 4.77 & 16.44 & 0.16 \\
\hline Miliusa tomentosa & 6.56 & 3.42 & 3.41 & 13.39 & 0.53 \\
\hline Azadirachta indica & 4.04 & 4.89 & 3.32 & 12.25 & 0.16 \\
\hline Acacia catechu & 4.16 & 5.38 & 2.05 & 11.59 & 0.14 \\
\hline Madhuca longifolia & 0.76 & 2.93 & 7.71 & 11.40 & 0.08 \\
\hline Tamarindus indica & 0.88 & 2.20 & 6.49 & 9.58 & 0.16 \\
\hline Eucalyptus hybrid & 1.77 & 2.93 & 4.25 & 8.95 & 0.19 \\
\hline Ficus religiosa & 0.25 & 0.98 & 7.64 & 8.87 & 0.25 \\
\hline Ficus benghalensis & 2.27 & 0.98 & 4.29 & 7.53 & 2.25 \\
\hline Diospyros melanoxylon & 3.15 & 2.93 & 1.23 & 7.32 & 0.35 \\
\hline Holoptelea integrifolia & 1.77 & 2.44 & 0.88 & 5.09 & 0.28 \\
\hline Aegle marmelos & 1.64 & 1.47 & 0.62 & 3.73 & 0.72 \\
\hline Bauhinia racemosa & 1.39 & 1.47 & 0.75 & 3.60 & 0.61 \\
\hline Sterculia urens & 0.63 & 1.47 & 1.27 & 3.37 & 0.28 \\
\hline Canavalia ensiformis & 1.26 & 1.47 & 0.55 & 3.27 & 0.56 \\
\hline Dalbergia sissoo & 1.01 & 0.98 & 1.16 & 3.14 & 1.00 \\
\hline Vachellia nilotica & 1.01 & 1.47 & 0.65 & 3.13 & 0.44 \\
\hline Morinda pubescens & 0.76 & 1.96 & 0.23 & 2.94 & 0.19 \\
\hline Ricinus communis & 1.13 & 1.47 & 0.24 & 2.84 & 0.50 \\
\hline Andrographis paniculata & 0.76 & 0.98 & 0.80 & 2.53 & 0.75 \\
\hline Dolicandrone falcate & 0.25 & 0.49 & 1.77 & 2.51 & 1.00 \\
\hline Zizyphus xyiopyra & 1.13 & 0.98 & 0.34 & 2.45 & 1.13 \\
\hline Bridelia retusa & 0.63 & 1.47 & 0.33 & 2.43 & 0.28 \\
\hline Garuga pinnata Roxb & 0.63 & 0.98 & 0.81 & 2.42 & 0.63 \\
\hline Mitragyna parvifolia & 0.38 & 0.98 & 0.84 & 2.19 & 0.38 \\
\hline Lannea coromandelica & 0.63 & 0.98 & 0.52 & 2.13 & 0.63 \\
\hline Ficus racemose & 0.88 & 0.98 & 0.25 & 2.11 & 0.88 \\
\hline Terminalia bellirica & 0.38 & 1.47 & 0.18 & 2.02 & 0.17 \\
\hline Prosopis juliflora & 0.38 & 0.98 & 0.48 & 1.84 & 0.38 \\
\hline Anogeissus latifolia & 0.38 & 0.98 & 0.19 & 1.55 & 0.38 \\
\hline Anacardium occidentale, & 0.76 & 0.49 & 0.30 & 1.54 & 3.00 \\
\hline Annona squamosal & 0.25 & 0.98 & 0.21 & 1.44 & 0.25 \\
\hline Pongamia pinnata & 0.25 & 0.98 & 0.12 & 1.35 & 0.25 \\
\hline Carissa Carandas & 0.25 & 0.98 & 0.03 & 1.26 & 0.25 \\
\hline Ficus virens & 0.38 & 0.49 & 0.26 & 1.13 & 1.50 \\
\hline Mitragyna parviflora & 0.25 & 0.49 & 0.11 & 0.85 & 1.00 \\
\hline Cassia fistula & 0.25 & 0.49 & 0.11 & 0.85 & 1.00 \\
\hline Albizia labbeck & 0.13 & 0.49 & 0.18 & 0.80 & 0.50 \\
\hline Cordia dichotoma & 0.13 & 0.49 & 0.11 & 0.73 & 0.50 \\
\hline Alangium salviifolium & 0.13 & 0.49 & 0.09 & 0.71 & 0.50 \\
\hline Phyllanthus emblica & 0.13 & 0.49 & 0.08 & 0.70 & 0.50 \\
\hline Bombax ceabae & 0.13 & 0.49 & 0.04 & 0.65 & 0.50 \\
\hline Manilkara Hexandra & 0.13 & 0.49 & 0.03 & 0.65 & 0.50 \\
\hline Securinega leucopyrus & 0.13 & 0.49 & 0.03 & 0.64 & 0.50 \\
\hline Ailanthus excelsa Roxb & 0.13 & 0.49 & 0.00 & 0.62 & 0.50 \\
\hline Acacia leaucophlea & 0.13 & 0.49 & 0.00 & 0.62 & 0.50 \\
\hline
\end{tabular}


that Holorrhena antidysenterica, $70.23 \%$ of total) is dominant and which is spread all over the study site. Holarrhena antidysenterica is good indicator species of healthy teak forest (Majumdar et al 2012). It is primarily used for the treatment of dysentery but has several other therapeutic usages but locally it is used for fodder and fuelwood purposes. The other three species have the lowest IVI value with less Relative density, Frequency, and Dominance showing that few numbers of these species were present in the area. Wrightia tinctoria R.Br, Ceasalpinia bonduc,

Table 3. Vegetation parameters of saplings

\begin{tabular}{|c|c|c|c|c|c|}
\hline Name of species & Relative density & Relative frequency & Relative dominance & $\begin{array}{l}\text { Important value } \\
\text { index }\end{array}$ & $\begin{array}{c}\text { Abundance/ } \\
\text { Frequency ratic }\end{array}$ \\
\hline Butea monosperma & 30.06 & 22.92 & 40.04 & 93.02 & 0.1 \\
\hline Tectona grandis & 21.17 & 17.71 & 15.8 & 54.68 & 0.12 \\
\hline Canavalia ensiformis & 8.59 & 7.29 & 9.34 & 25.22 & 0.29 \\
\hline Diospyros melanoxylon & 6.44 & 7.29 & 3.94 & 17.67 & 0.21 \\
\hline Terminalia arjuna & 2.76 & 3.13 & 3.27 & 9.15 & 0.5 \\
\hline Acacia catechu & 4.29 & 3.13 & 1.43 & 8.85 & 0.78 \\
\hline Aegle marmelos & 3.99 & 3.13 & 1.68 & 8.8 & 0.72 \\
\hline Morinda pubescens & 2.76 & 5.21 & 0.37 & 8.34 & 0.18 \\
\hline Ficus racemose & 0.92 & 1.04 & 6.2 & 8.16 & 1.5 \\
\hline Terminalia crenulata & 3.07 & 3.13 & 1.75 & 7.94 & 0.56 \\
\hline Prosopis juliflora & 1.23 & 2.08 & 3.28 & 6.59 & 0.5 \\
\hline Azadirachta indica & 1.23 & 2.08 & 3.13 & 6.44 & 0.5 \\
\hline Dolicandrone falcate & 2.15 & 1.04 & 2.84 & 6.03 & 3.5 \\
\hline Miliusa tomentosa & 2.15 & 3.13 & 0.46 & 5.73 & 0.39 \\
\hline Cassia fistula & 0.92 & 2.08 & 2.51 & 5.51 & 0.38 \\
\hline Holoptelea integrifolia & 1.53 & 3.13 & 0.4 & 5.06 & 0.28 \\
\hline Cordia dichotoma & 1.23 & 3.13 & 0.62 & 4.98 & 0.22 \\
\hline Carissa carandas & 1.53 & 1.04 & 0.92 & 3.5 & 2.5 \\
\hline Anogeissus pendula & 1.23 & 2.08 & 0.12 & 3.43 & 0.5 \\
\hline Mitragyna parvifolia & 0.92 & 1.04 & 0.75 & 2.72 & 1.5 \\
\hline Manilkara Hexandra & 0.31 & 1.04 & 0.94 & 2.29 & 0.5 \\
\hline Zizyphus mauritiana & 0.61 & 1.04 & 0.04 & 1.7 & 1 \\
\hline Acacia leucophlea & 0.31 & 1.04 & 0.07 & 1.42 & 0.5 \\
\hline Eucalyptus hybrid & 0.31 & 1.04 & 0.05 & 1.39 & 0.5 \\
\hline Anogeissus latifolia & 0.31 & 1.04 & 0.03 & 1.37 & 0.5 \\
\hline
\end{tabular}

Table 4. Vegetation parameters for shrub species

\begin{tabular}{|c|c|c|c|c|c|}
\hline Name of species & Relative density & Relative frequency & $\begin{array}{c}\text { Relative } \\
\text { dominance }\end{array}$ & $\begin{array}{c}\text { Important value } \\
\text { index }\end{array}$ & $\begin{array}{c}\text { Abundance/freque } \\
\text { ncy ratio }\end{array}$ \\
\hline Holorrhena antidysenterica & 76.63 & 53.23 & 80.86 & 210.72 & 0.09 \\
\hline Wrightia tinctoria $R . B r$ & 8.43 & 11.29 & 12.16 & 31.88 & 0.22 \\
\hline Ceasalpinia bonduc & 4.98 & 11.29 & 3.53 & 19.80 & 0.13 \\
\hline Lantana camara & 3.07 & 6.45 & 1.32 & 10.84 & 0.25 \\
\hline Calotropis gigantean & 2.68 & 6.45 & 1.41 & 10.55 & 0.22 \\
\hline Carissa Carandas & 1.15 & 4.84 & 0.00 & 5.99 & 0.17 \\
\hline Ipomea fistula & 1.92 & 3.23 & 0.71 & 5.85 & 0.63 \\
\hline Vitex nirgunda & 0.77 & 1.61 & 0.00 & 2.38 & 1.00 \\
\hline Ricinus communis & 0.38 & 1.61 & 0.00 & 2.00 & 0.50 \\
\hline
\end{tabular}


Lantana camaraare co-dominant species followed by Calotropis gigantean, Carissa carandus, Ipomea fistula, Vitex nirgunda and Ricinus communis In the study area there is less number of invasive species were recorded i.e. Prosopis juliflora and Lantana camara. This is also a good indicator of a healthy forest as it secrets the chemical which suppresses the growth of other species.

Climbers/Grasses/herbs: Eleven Species of Climbers/Herbs/ Grasses /weed were recorded from the study area (Table 5). Importance value index (IVI) showing that Bambusa vulgaris (108.3\% of total) is dominant which is distributed in patches all over the study area. Canavalia ensiformis, Cynodon dactylon, Parthenium hysterophorus, Mollugo verticillata IVI are co-dominant species followed by Heliotropium supinum, Sida cordata, Ventilago denticulata Willd. Celastrus paniculatus, Curcuma arometica has the lowest IVI value with less relative density, frequency, and dominance and it is showing that less in a number of these species were present in the area.

Dominant species: The total Density of all the individual tree species is higher as compared to saplings in the study area. This may be possible for these species may disappear soon in near future. The highest density/ha was recorded by Butea monosperma (108 plants/ha) of tree species and followed by Tectona grandis \& Terminalia arjuna. But the number of saplings and regeneration were less than tree species this

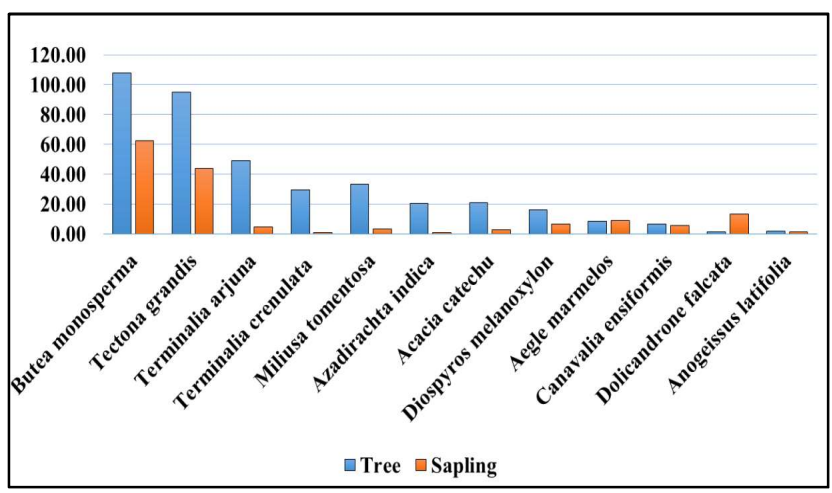

Fig. 3. Density per hectare of dominant species

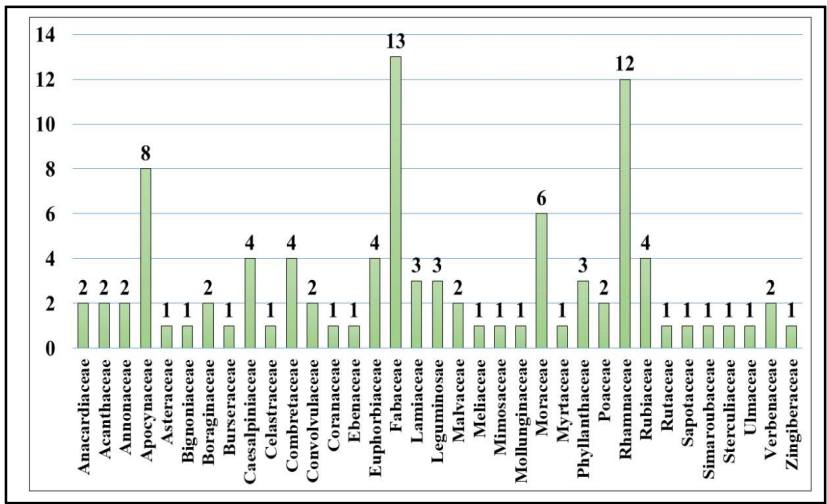

Fig. 4. Family wise number of species at the study site

Table 5. Vegetation parameters of Climbers/Grasses/Herbs

\begin{tabular}{|c|c|c|c|c|c|}
\hline Botanical name & R.D & R.F & R.A & IVI & $\mathrm{A} / \mathrm{F}$ \\
\hline Bambusa vulgaris (Long grass) & 17.93 & 4.9505 & 28.44 & 51.32 & 0.66 \\
\hline Canavalia ensiformis (Climbers) & 15.76 & 21.78 & 5.68 & 43.22 & 0.03 \\
\hline Cynodon dactylon (Grass) & 14.67 & 20.79 & 5.54 & 41 & 0.03 \\
\hline Parthenium hysterophorus (Grass) & 13.59 & 18.81 & 5.67 & 38.06 & 0.03 \\
\hline Mollugo verticillata (Herb) & 13.04 & 6.93 & 14.77 & 34.74 & 0.24 \\
\hline Heliotropium supinum (Weed) & 10.33 & 7.92 & 10.23 & 28.48 & 0.15 \\
\hline Sida cordata (Grass) & 4.891 & 4.95 & 7.75 & 17.59 & 0.18 \\
\hline Ventilago denticulata Willd.(Climber) & 3.804 & 3.96 & 7.54 & 15.30 & 0.22 \\
\hline Celastrus paniculatus (Climber) & 2.174 & 2.97 & 5.74 & 10.89 & 0.22 \\
\hline Tinospora cordifoilia (Gado) (Climber) & 2.174 & 3.96 & 4.31 & 10.44 & 0.13 \\
\hline Curcuma arometica (Herb) & 1.63 & 2.97 & 4.31 & 8.90 & 0.17 \\
\hline
\end{tabular}

Table 6. Species diversity indices

\begin{tabular}{|c|c|c|c|c|}
\hline Diversity indices & Shannon index & Simpson index ${ }^{* *}$ & No. of species & Diversity \\
\hline Trees & 2.83 & 0.10 & 49 & Extremely high \\
\hline Sapling & 2.39 & 0.15 & 25 & Extremely high \\
\hline Shrub & 0.81 & 0.65 & 20 & Moderate \\
\hline Herbs/Grass/Climber & 2.16 & 0.12 & 11 & Extremely high \\
\hline
\end{tabular}

** Lower the value higher the diversity 
indicating that the forest is being utilized by the local people. Terminalia arjuna regeneration status was lower than tree species may be due to exploitation of the species and it is endangered species of Gujarat so it is important to the conservation of these plant species (Fig. 3). Teak has many economic benefits as it is considered to be one of the world's most important woody species due to its valuable timber (Pandey and Brown, 2000).At the study site, the member of the panchayat sell teak wood for their economic benefits.

Family wise number of species: The Lamiaceae family is mainly essential to human beings for herb species useful for medicinal properties, flavor, fragrance, valuable in food, cosmetics, pesticide, and pharmaceutical industries. Total 13 individual species were recorded higher from family Lamiaceae which by Asteraceae Moraceae, Coranaceae and Phyllanthaceae (Fig. 4) is followed by the Rhamnaceae family 12 individual plant species, followed

Diversity indices of tree/saplings/herb/shrub: It takes into account the number of species present, as well as the abundance of each species. The total of 49 trees, 25 saplings, 20 Shrub and 11 herb/climber/grass were collected (Table 6) with a diversity of Shannon index $\left(\mathrm{H}^{\prime}\right)$ 2.83, 2.39, 0.81 , and 2.16 in the study area where the lower value of Simpson index also indicating that the diversity of species is higher at the study site.

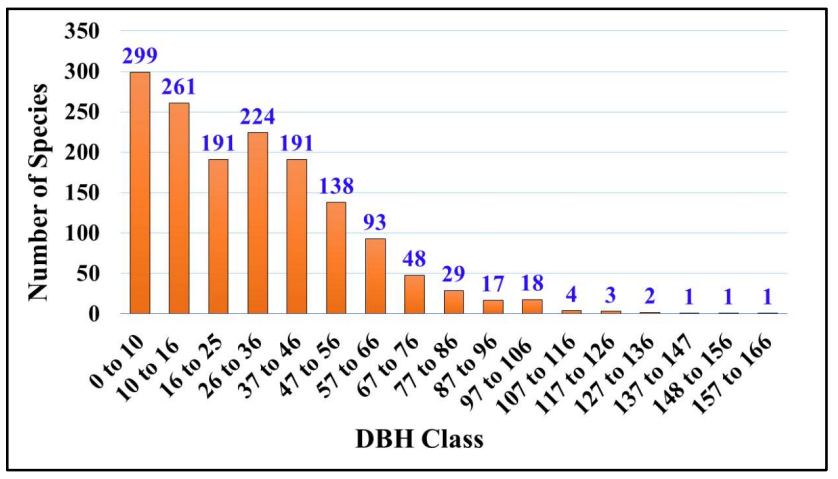

Fig. 5. DBH class of plant species

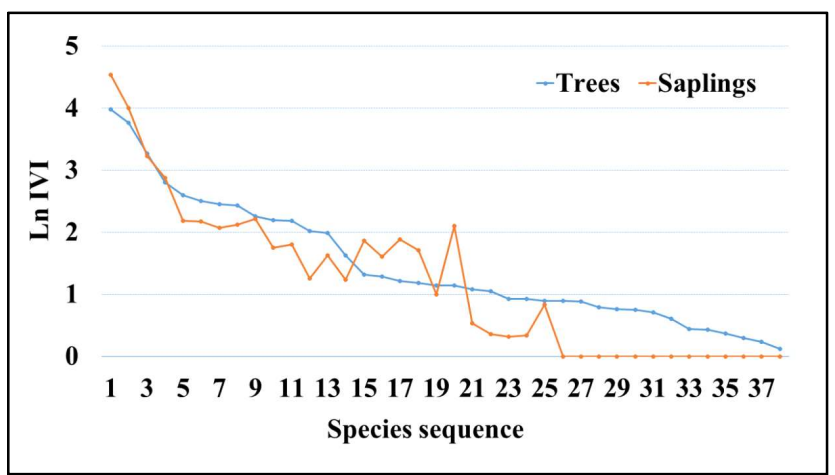

Fig. 6. Dominance-diversity curve
DBH class of plant species: DBH class of plant species in the area it indicates that the higher number of species found in the study site was between 0 to $10 \mathrm{~cm} \mathrm{DBH} \mathrm{(Fig.} \mathrm{5).} \mathrm{This}$ indicates that the forest is newly planted or newly regenerated. These immature trees have the potential to absorb more carbon making higher carbon stock. However, the forest has a higher potential to grow and sequestrates more carbon. The maximum number of individual plant species was Shannon index $\left(\mathrm{H}^{\prime}\right)$ above $36 \mathrm{~cm}$ DBH mature woody trees in the selected area that indicates the community is protecting the mature trees.

Dominance-diversity curve of tree species: The interrelationship among the species of the area with respect to the resources is tried to be understood after drawing the dominance diversity curve for the study area (Fig. 6) The diversity-dominance curve showing where species ranked from most to least abundant and the majority of the species had lower abundance and population, while few species showed higher values. Butea monosperma and Tectona grandis appeared to be the most abundant in the forest. the curve is more towards geometric series distribution exhibited log-normal condition and represents high diversity condition. This type of distribution is foundin a community where species richness is very good and all the environmental parameter is good enough for the survival of species. Besides serious past logging experience for timber, several other anthropogenic disturbances were still ongoing but to some limited extent. Grazing and fuelwood collection was more intense at the site.

Role of community participation in conserving the forest resources: Interviews were taken for the information about the village people's participation and field observation in conserving the forest resources and their utilization sustainably. All these selected villages are associated with the forest region (community reserved forest). The plantation was done by Surat Van Vibhag Samiti in a degraded forest for afforestation. The community people are very much aware of Biodiversity conservation \& its act. They conserve the forest

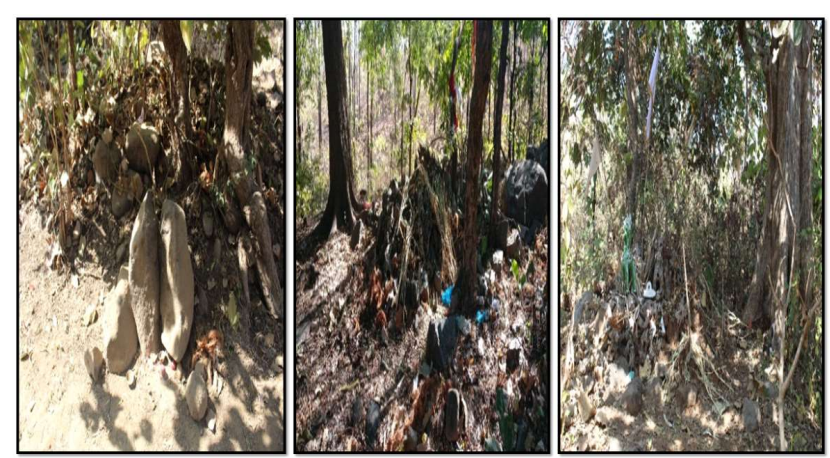

Fig. 7. Conservation through traditional belief 
Table 7. Biomass andcarbon sequestration of dominant species

\begin{tabular}{|c|c|c|c|c|}
\hline \multirow{2}{*}{$\begin{array}{l}\text { Biomass \& carbon stock of tree/saplings } \\
\text { Name of species }\end{array}$} & \multicolumn{2}{|c|}{ Tree } & \multicolumn{2}{|c|}{ Sapling } \\
\hline & Biomass ( $T$ ha $\left.{ }^{-1}\right)$ & $\mathrm{CO}_{2}\left(\mathrm{~T} \mathrm{ha}^{-1}\right)$ & Biomass ( $\mathrm{T} \mathrm{ha}^{-1}$ ) & $\mathrm{CO}_{2}\left(\mathrm{~T} \mathrm{ha}^{-1}\right)$ \\
\hline Butea monosperma & 356 & 160 & 14 & 10 \\
\hline Tectona grandis & 257 & 116 & 8 & 5 \\
\hline Terminalia arjuna & 164 & 74 & 1 & 0 \\
\hline Terminalia crenulata & 90 & 41 & 1 & 1 \\
\hline Miliusa tomentosa & 57 & 26 & 1 & 1 \\
\hline Azadirachta indica & 66 & 30 & 1 & 1 \\
\hline Acacia catechu & 67 & 30 & 1 & 1 \\
\hline Madhuca longifolia & 347 & 156 & - & - \\
\hline Tamarindus indica & 251 & 113 & - & - \\
\hline Eucalyptus hybrid & 110 & 49 & 0 & 0 \\
\hline Ficus religiosa & 404 & 182 & - & - \\
\hline Ficus benghalensis & 142 & 64 & - & - \\
\hline Diospyros melanoxylon & 19 & 9 & 2 & 1 \\
\hline Aegle marmelos & 10 & 5 & 1 & 1 \\
\hline Bauhinia racemosa & 13 & 6 & - & - \\
\hline Total & 2352 & 1058 & 29 & 21 \\
\hline
\end{tabular}

through their traditional beliefs, customs, or religious rules (Fig. 7). The nursery was established for forest vegetation management by the Surat Municipal Corporation, maintenance of that nursery and plantation is done by local people only. It is evident from the survey, that the local people can play a significant role in conserving the forest and its resources.

Biomass and carbon sequestration of dominant species: Tectona grandis has the highest value of Biomass tonnes per hectares among all the species as it has the higher value of basal area and volume of a species (Table 7). The basal area is a good indicator for biomass and carbon meanwhile it combines the effect of the size and number of trees. The basal area and biomass of the species-area related to tree diameter, so, the correlation between these two variables can be expected. Among the species found in the forest area, the carbon stock was highest in species Butea monosperma (160 ton/ha), Tectona grandis (116 ton/ha). Mature woody plants capture three times more $\mathrm{CO} 2$. Mature trees store more carbon and are very important for biodiversity by providing shelter to many creatures to survive. They keep store carbon but no longer remove much carbon from the atmosphere as new growth is offset by some decayingof deadwood. The growing plant species capture more carbon from the atmosphere for their growth but are too small to be a significant store of carbon. So, it could be good if every year plantation should be done at the site as it is evident from the study that the saplings are less as compared to mature plants.

\section{CONCLUSION}

Floristic diversity and it structural composition of any particular forest is very much important for ecosystem stability. Butea monosperma, Tectona grandis and Terminalia Arjuna were the dominant species and less number of exotic species present at the study site. The area was covered by the highest percent of mature woody tree species is more as compared to saplingsfollowed by shrub, herbs. climbers and grasses. The overall density of saplings was less than tree species which we can understand the forest will become less dense in the near future so there is an urgent need to focus on regereration status of the forest area. The area comprises endangered species (Terminalia arjuna, Celastrus paniculatus, Tinospora cordifolia, with higher medicinal importance and traditional use. The conservation of these species in the natural habitat will help the local people for their primary treatment as well as an economic benefit. This study will deliver the baseline for further study in this area and the development of conservation as well as proper management strategies for important plant species.

\section{ACKNOWLEDGMENT}

Authors would like to thank Gujarat Ecological Education and Research Foundation for plant species identification.

\section{REFERENCES}

Aalde H, Gonzalez P, Gytarsky M, Krug T, Kurz W, Ogle S . . Elhassan N 2006. Chapter 4: forest land. 2006 IPCC Guidelines for National Greenhouse Gas Inventories. 
Ali S, Zeb U, Lei W, Khan H, Shehzad K, Khan H and Ullah I 2018. Floristic inventory and ecological characterization the village Sherpao, District Charsadda, Khyber Pakhtunkhwa-Pakistan. Acta Ecologica Sinica 38(5): 329-333.

Brown S 1997. Estimating biomass and biomass change of tropical forests: A primer (Vol. 134): Food \& Agriculture Org.

Cannon CH, Peart DR and Leighton M 1998. Tree species diversity in commercially logged Bornean rainforest. Science, 281(5381): 1366-1368.

Chapin lii FS, Zavaleta ES, Eviner VT, Naylor RL, Vitousek PM, Reynolds HL . . Hobbie SE 2000. Consequences of changing biodiversity. Nature 405(6783): 234-242.

Curtis JT 1956. Plant ecology workbook. A laboratory, field and reference manual. Plant ecology workbook. A laboratory, field and reference manual.

Dhaulkhandi M, Dobhal A, Bhatt S and Kumar M 2008. Community structure and regeneration potential of natural forest site in Gangotri, India. Journal of Basic and Applied Sciences 4(1): 4952.

Eliasch J 2008. Climate change: Financing global forests: the Eliasch review: Earthscan.

Gaston KJ and Spicer JI 2013. Biodiversity: An introduction: John Wiley \& Sons.

Huston MA and Huston MA 1994. Biological diversity: The coexistence of species: Cambridge University Press.

Kellogg WW 2019. Climate change and society: Consequences of increasing atmospheric carbon dioxide: Routledge.

Received 18 October, 2021; Accepted 28 December, 2021
Kerkhoff A 2010. Measuring biodiversity of ecological communities. Biology 4: 229.

Majumdar K, Shankar U and Datta BK 2012. Tree species diversity and stand structure along major community types in lowland primary and secondary moist deciduous forests in Tripura, Northeast India. Journal of Forestry Research 23(4): 553-568.

Pandey D and Brown C 2000. Teak: A global overview. UNASYLVAFAO-, 3-13.

Ratter JA, Bridgewater S and Ribeiro JF 2003. Analysis of the floristic composition of the Brazilian cerrado vegetation III: comparison of the woody vegetation of 376 areas. Edinburgh Journal of Botany 60(1): 57.

Shannon CE and Weaver W 1949. The mathematical theory of communication. University of Illinois. Urbana, 117.

Shirima DD, Totland $\varnothing$, Munishi PK and Moe SR 2015. Relationships between tree species richness, evenness and aboveground carbon storage in montane forests and miombo woodlands of Tanzania. Basic and Applied Ecology 16(3): 239-249.

Singh J 2002. The biodiversity crisis: A multifaceted review. Current Science, 638-647.

Stohlgren TJ, Falkner M and Schell L 1995. A modified-Whittaker nested vegetation sampling method. Vegetatio 117(2): 113121.

Tiwari OP, Rana YS, Krishan R, Sharma CM and Bhandari BS 2018. Regeneration dynamics, population structure, and forest composition in some ridge forests of the Western Himalaya India. Forest Science and Technology 14(2): 66-75. 